Article - Biological and Applied Sciences

\title{
Bioactive Compounds and Antioxidant Activity in Leaves of Endemic and Native Isatis spp in Turkey
}

\author{
Nazan Comlekcioglu ${ }^{1 *}$ \\ https://orcid.org/0000-0001-7729-5271 \\ ${ }^{1}$ Kahramanmaras Sutcu Imam University, Science and Art Faculty, Biology Department, \\ Kahramanmaras, Turkey
}

Received: 2018.06.02; Accepted: 2019.06.22.

* Correspondence: noktem80@gmail.com; Tel.: +90-344-3001414

\section{HIGHLIGHTS}

- I. tinctoria and I. buschiana had the highest protein and fatty oil content.

- Gluconapin was the main glucosinolate in Isatis spp., except I. tinctoria.

- I. buschiana was found rich in both phenolic and flavonoid compounds.

- I. buschiana exhibited the highest antioxidant activity.

Abstract: This study was undertaken to evaluate the health-promoting potentials of Isatis aucherii, Isatis buschiana, Isatis candolleana, Isatis tinctoria subsp. corymbosa and Isatis tinctoria. I. aucherii and I. candolleana are endemic, I. buschiana, I. tinctoria subsp. corymbosa are native in Turkey. While $I$. tinctoria is a well studied species, there is insufficient information about other endemic and native species. Therefore, this study is focused to reveal the bioactive compounds of poorly studied endemic and native species. In this context, protein, ash, glucosinolates, fatty acids, total phenolic and flavonoid content, and antioxidant activities were determined in leaf extracts. The highest protein and fatty oil contents were observed in I. tinctoria and I. buschiana. Arachidic acid was predominant in $I$. tinctoria subsp. corymbosa, I. buschiana and I. aucherii, while predominant fatty acids were arachidonic and oleic acids in I. candolleana and I. tinctoria. Glucobrassicin was the main glucosinolate in I. tinctoria, while the others contained gluconapin as the main glucosinolate. Antioxidant activities were correlated with phenolic and flavonoid content, the highest and lowest antioxidant activities were observed in I. buschiana and I. aucherii, respectively. 
According to results, I. buschiana leaves were high in contents of bioactive compounds; it could be a promising plant with its health- promoting effects.

Keywords: Antioxidant activity, fatty acids, flavonoid, glucosinolate, Isatis, phenolic.

\section{INTRODUCTION}

Glucosinolates are a group of nitrogen and sulphur-containing secondary metabolites [1] and they are present in sixteen families of dicotyledonous angiosperms [2]. When the plants are damaged, for example by a cut or chew the hydrolysis of glucosinolates by thioglucosidases called myrosinase (EC 3.2.1.147) produces different products such as isothiocyanates, thiocyanates, and nitriles [1]. The glucosinolate-myrosinase system is a defense mechanism of plants against several insects and pathogens [3]. Many isothiocyanates are known for their anticarcinogen effect, therefore the use of glucosinolates as potential chemoprotectors against cancer have attracted the scientific interest [4]. A reduced risk of cancer has been associated with the consumption of glucosinolate containing Brassica vegetables [5].

The Brassicaceae family which is one of the 10 most economically important plant families in the world, contains 338 genera and 3350 species that are distributed worldwide $[2,6]$. Turkey is the second rich country regarding the number of species of the Brassicaceae, following the United States [7]. Besides providing glucosinolates, Brassicaceae vegetables are also an excellent dietary source of phenolics, antioxidants like vitamins, dietary essential minerals, and flavonoids [8]. The content and composition of glucosinolates vary according to plant species, environmental conditions, and agronomic practises [9]. The Isatis genus is biennial, a herbaceous shrub belonging to family Brassicaceae and, which has about 79 species in the world, is a plant of Mediterranean, Eastern and Central Asia, and is distributed in most Iran-Turan phytogeographic regions. Isatis is represented by 34 species, 16 subspecies and two varieties in Turkey and 20 of these 34 species and 5 of 16 subspecies are endemic [10]. The general characteristics of Isatis genus are single, two or multi-year; $50-100 \mathrm{~cm}$ in length, with yellow flowers, leaves are described as hairy or hairless [11]. Phytochemical, biological and pharmacological properties of $I$. tinctoria, known for its blue dye (indigo), have been investigated due to their medicinal properties $[12,13]$. Glucosinolates, such as epiprogoitrin, progoitrin, gluconapin, glucotropaeolin, glucobrassicin, neoglucobrassicin, sulfoglucobrassicin and 4-hydroxyglucobrassicin, were detected in $I$. tinctoria $[1,14,15]$. I. indigotica, I. microcarpa and I. canescens were investigated for their glucosinolates by Mohn and Hamburger [16], Emam and El-Moaty [17] and Galletti et al. [18], respectively.

Fatty acid contents were investigated in seeds of $I$. aucherii and $I$. candolleana $[19,20]$. Dyeing properties of $I$. candolleana, I. buschiana and I. tinctoria subsp. corymbosa were examined by using low-technology methods [21]. Brassicaceae collects various phenolic compounds that act as antioxidants in rosette leaves, and these leaves also have anti-inflammatory and anti-allergic activity [22]. Leaves are industrially and pharmacologically important part of $I$. tinctoria, therefore leaves of Isatis spp. were studied in this study. The aim of the present study was to determine the glucosinolate, total phenolic and flavonoid, and fatty acid content of Isatis species, I. aucherii Boiss. (endemic to Turkey), I. candolleana Boiss., (endemic to Turkey); I. buschiana Schischkin, I. tinctoria L. subsp. corymbosa Boiss. from Turkey and I. tinctoria (culture form). While some bioactive molecules of several Isatis spp. have been examined [18, 23-26], to the best of our knowledge, fatty acids, glucosinolates, total phenolic and flavonoid contents and antioxidant activities of leaves of $I$. aucherii, I. buschiana, I. candolleana and I. tinctoria subsp. corymbosa, of $I$. buschiana and I. tinctoria subsp. corymbosa were reported firstly in this study. 


\section{MATERIAL AND METHODS}

\section{Plant Material}

Wild $I$. aucherii (endemic) and $I$. candolleana (endemic) plants were collected from Ahir Mountain in Kahramanmaraş (city center) in June (altitude $960 \mathrm{~m}$ ). Wild I. tinctoria subsp. corymbosa and $I$. buschiana plants were collected from native stands in GöksunKahramanmaras in June (altitude of 1300-1400 m and 1200-1250 m, respectively). Plants were identified according to Flora of Turkey [11]. The city center and Göksun country in Kahramanmaras province, where the wild plants were collected, have Mediterranean and Mediterranean-Terrestrial climates, respectively. The seeds of $I$. tinctoria were provided from IPK-Institute for Plant Genetics and Crop Plant Research, Gatersleben, Germany and were grown in Kahramanmaras/Turkey.

\section{Sample preparation}

Leaves were harvested from 10 individual plants of each Isatis species. To prevent any changes in the composition, leaves were separately soaked in liquid nitrogen immediately after the harvest, and then freeze-dried in a lyophilizator (CHRIST Freeze Dreyer, Alpha 1-2 LD) at $-50^{\circ} \mathrm{C}$ before analysis. Freeze-dried samples were homogenized in a laboratory blender (Waring Commercial) and stored at $-86^{\circ} \mathrm{C}$ until use.

\section{Determination of ash and protein content}

The ash content was determined following the European standard method UNIEN 14775 [27]. The protein content of the samples was determined by using AOAC [28] method. Analyses were made by using $5 \mathrm{~g}$ and $2 \mathrm{~g}$ freeze-dried leaf samples for ash and protein methods, respectively. All experiments were carried out in triplicate.

\section{Determination of Fatty Acid Content}

For fatty acids in plant extract, ground samples $(10 \mathrm{~g})$ were extracted in a Soxhlet extraction apparatus with petroleum ether (Merck) as a solvent. After extraction, the ether was removed entirely by rotary evaporation. Fatty acid methyl esters of Isatis species were prepared with alkaline transmethylation [29]. GC-MS analyses were quantified using a Shimadzu 2025 gas chromatograph (Shimadzu, Kyoto, Japan) equipped with a Shimadzu AOC-20i automatic sampler (Shimadzu, Kyoto, Japan). The condition of GC analysis was as follows: flame ionization detector (FID) $250^{\circ} \mathrm{C}$; column TR-CN100, $60 \mathrm{~m} \times 0.25 \mathrm{~mm} \times 0.20$ $\mathrm{mm}$ (Teknokroma); carrier gas was Helium with a flow rate of $1.5 \mathrm{~mL} / \mathrm{min}$. Fatty acid peaks were identified against the chromatogram of a mixed fatty acid methyl ester standard (37 Comp. FAME Mix $10 \mathrm{mg} / \mathrm{mL}$ in $\mathrm{CH}_{2} \mathrm{Cl}_{2}$; Supelco, USA). The injector and detector temperatures were kept at $250^{\circ} \mathrm{C}$. The column oven temperature was programmed at $80^{\circ} \mathrm{C}$ for 2 min initially, then $5^{\circ} \mathrm{C} / \mathrm{min}$ up to $140^{\circ} \mathrm{C}$ (maintained for 2 min at $140^{\circ} \mathrm{C}$ ), and then $3^{\circ} \mathrm{C} / \mathrm{min}$ up to $240^{\circ} \mathrm{C}$ (maintained for $5 \mathrm{~min}$ at $240^{\circ} \mathrm{C}$ ). The injection and detector temperatures were set at 240 and $250^{\circ} \mathrm{C}$, respectively. The fatty acids were expressed as the percentage of the total fatty acids, calculated with peak areas.

\section{Extraction of Intact Glucosinolates and HPLC Analysis}

The intact glucosinolate amounts were measured according to Mohn et al. [1] with modifications. Glucosinolates were extracted from $200 \mathrm{mg}$ of powdered samples in $5 \mathrm{~mL}$ of methanol: $\mathrm{ddH}_{2} \mathrm{O}(70: 30, \mathrm{v} / \mathrm{v})$ by ultrasonication at $50^{\circ} \mathrm{C}$ for $30 \mathrm{~min}$ and centrifuged for $15 \mathrm{~min}$ at $6000 \mathrm{~g}$ and $4^{\circ} \mathrm{C}$. Methanol was removed by using rotavapor (IKA HB4 Basic) at $40{ }^{\circ} \mathrm{C}$ and the extract was stored at $-20^{\circ} \mathrm{C}$ for further studies. 
The dried extracts were dissolved in $1 \mathrm{~mL}$ of $10 \mathrm{mM}$ ammonium formate. Separations were carried out on a C18 column (Nuclesil 100-5 C18, $250 \times 4.6 \mathrm{~mm}$ ) using a Hitachi L-2400 HPLC equipped with UV detector. Mobil phase A consisted of a solution of $10 \mathrm{mM}$

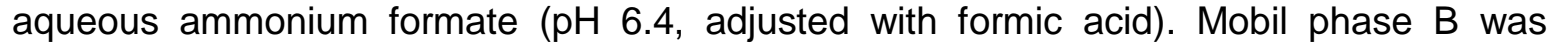
acetonitrile. A linear gradient starting at $0.5 \% \mathrm{~B}$ to $1.0 \% \mathrm{~B}$ (2 min), $1.0 \% \mathrm{~B}$ to $3.0 \% \mathrm{~B}$ (3 min), $3.0 \%$ B to $4.0 \%$ B (2 min), $4.0 \%$ B to $10.0 \%$ B (3 min), $10.0 \%$ B to $12.0 \%$ B (2 min), $12.0 \%$ B to $15.0 \% \mathrm{~B}$ (3 $\mathrm{min}), 15.0 \% \mathrm{~B}$ to $15.0 \% \mathrm{~B}$ (5 min), $15.0 \% \mathrm{~B}$ to $0.5 .0 \% \mathrm{~B}$ (5 min), $0.5 \% \mathrm{~B}$ to $0.5 \% \mathrm{~B}(15 \mathrm{~min})$ was used for the separation of glucosinolates. Flow rate was $1.0 \mathrm{~mL} / \mathrm{min}$. Column temperature was $25.0^{\circ} \mathrm{C}$. The sample injection volume was $20 \mu \mathrm{L}$. The glucosinolates detected by UV absorbance at $229 \mathrm{~nm}$. Calibration curves were calculated by using the glucosinolate standards of progoitrin $(y=38123 x+921,2)$, epiprogoitrin $(y=$ $32150 x+2732)$, gluconapin $(y=31855 x+2814)$, glucoerucin $(y=42791 x-2377)$ and glucobrassicin ( $y=17837 x-18245)$ and the $R^{2}$ values were higher than 0.990 . All measurements were conducted in triplicate and the mean values were used.

\section{Determination of Total Phenolic Content}

Powdered dry plant material $(0.1 \mathrm{~g} / 2 \mathrm{~mL})$ was extracted twice with 7:3 acetone: water $(\mathrm{v} / \mathrm{v})$ at $40^{\circ} \mathrm{C}$ for $30 \mathrm{~min}$ using ultrasonicator (ISOLAB Laborgerate $\mathrm{GmbH}$ ) and then centrifuged at $3500 \mathrm{~g}$ for $15 \mathrm{~min}$. The supernatants of both extraction cycles were combined. Then extract concentrated in a rotavapor under reduced pressure and stored at $-20^{\circ} \mathrm{C}$. Total phenolic contents of the fractions were determined using the Folin-Ciocalteau colorimetric method according to Blainski et al. [30] with minor modifications. Briefly, the stock solution of extracts $(300 \mu \mathrm{g} / \mathrm{mL})$ was prepared with $\mathrm{ddH}_{2} \mathrm{O}$. One $\mathrm{ml}$ of this stock extract solution was mixed with $5 \mathrm{ml}$ of $\mathrm{ddH}_{2} \mathrm{O}, 500 \mu \mathrm{l}$ of $2 \mathrm{~N}$ Folin-Ciocalteu's phenol reagent and $6 \mathrm{ml}$ of $10.75 \%$ $\mathrm{w} / \mathrm{v}$ anhydrous sodium carbonate $(\mathrm{w} / \mathrm{v})$. Blank was prepared by replacing the extract with ddH2O. After $30 \mathrm{~min}$, the absorbance against blank was measured at $760 \mathrm{~nm}$ in a UV-Vis spectrophotometer (Perkin-Elmer Lambda EZ 150, USA). Standard solutions of gallic acid $(0,1,2,3,4,5,6,7,8,9$ and $10 \mathrm{mg} / \mathrm{ml})$ were prepared immediately before use and measured by using the same procedure as described above. Calibration curve was calculated by using the gallic acid standard solutions $\left(y=0,142 x+0,021 ; R^{2}=0.992\right)$. The total phenolic content of plant materials was expressed as $\mathrm{mg}$ gallic acid equivalents $(\mathrm{GAE}) / \mathrm{g}$ dry weight. All experiments were analyzed in triplicates.

\section{Determination of Total Flavonoid Content}

Flavonoid compounds extracted from $0.5 \mathrm{~g}$ of powdered plant samples with $50 \mathrm{ml}$ of $80 \%$ methanol: water $(\mathrm{v} / \mathrm{v})$ using the ultrasonic bath for 20 min. Extraction solution was centrifuged for $5 \mathrm{~min}$ at $14000 \mathrm{rpm}$. The total flavonoid content in leaf extracts was determined spectrophotometrically according to Chang et al. [31]. An aliquot $(0.5 \mathrm{ml})$ of plant extract was added on to $1.5 \mathrm{ml}$ of methanol and $0.1 \mathrm{ml}$ of $1 \mathrm{M}$ potassium acetate $\left(\mathrm{CH}_{3} \mathrm{COOK}\right)$. This solution was mixed with $0.1 \mathrm{ml} \mathrm{AlCl}_{3}$ (1:10) and total volume was made up to $5 \mathrm{ml}$ with $\mathrm{dd}_{2} \mathrm{O}$. The solution was vortexed and incubated for $30 \mathrm{~min}$ at room temperature. Standard solutions were prepared as described above using quercetin. The absorbances

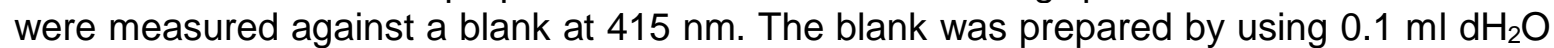
without $10 \%$ aluminum chloride. The standard curve was calculated with different concentrations $(0-100 \mu \mathrm{g} / \mathrm{ml})$ of quercetin $\left(y=0,0056 x-0,033 ; R^{2}=0.9956\right)$. The total flavonoid contents in plant extracts were determined as $\mu \mathrm{g}$ quercetin equivalents $\mathrm{g}$ - dried plant materials. All experiments were carried out in triplicate.

\section{DPPH radical-scavenging activity}


DPPH is a stable free radical that is considered a common tool to predict free radical scavenging activity of antioxidants [32]. Scavenging free radical potentials were determined using 1,1-Diphenyl-2-picrylhydrazyl (DPPH) according to the method described by Brand-Williams et al. [33] with minor modifications. Briefly, $50 \mu \mathrm{l}$ of five different concentrations of each plant extracts were mixed with $950 \mu \mathrm{l}$ of methanolic DPPH solution. The mixture left in darkness for 15 min at $25^{\circ} \mathrm{C}$ and the absorbance was measured at 517 $\mathrm{nm}$ against a reagent blank (50 $\mu \mathrm{l}$ of methanol+950 $\mu \mathrm{l}$ of DPPH methanolic solution). All experiments were carried out in triplicate. Ascorbic acid was used as positive control. Calibration curve was calculated by using the ascorbic acid standard solutions $(y=0,769 x+$ 0,$\left.014 ; R^{2}=0.995\right)$. The results were indicated as $I C_{50}$ value which is the concentration of sample required to scavenge $50 \%$ of DPPH free radicals. All experiments were carried out in triplicate.

\section{FRAP Activity}

FRAP reagent was prepared freshly $(2.5 \mathrm{~mL}$ of a $10 \mathrm{mmol} / \mathrm{l} \mathrm{TPTZ} \mathrm{solution} \mathrm{in} 40 \mathrm{mmol} / \mathrm{I}$ $\mathrm{HCl}, 2.5 \mathrm{~mL}$ of $20 \mathrm{mmol} / / \mathrm{FeCl}_{3}$ and $25 \mathrm{~mL}$ of $0.1 \mathrm{~mol} / \mathrm{l}$ acetate buffer, $\mathrm{pH} 3.6$ ) and incubated at $37^{\circ} \mathrm{C}$ for $10 \mathrm{~min}$ before the analysis. Then, $50 \mu \mathrm{l}$ of Isatis leaf extracts, $600 \mu \mathrm{l}$ of FRAP reagent and $1 \mathrm{~mL}$ of $\mathrm{ddH}_{2} \mathrm{O}$ was transferred into a 2-mL microcentrifuge tube. The obtained blue solutions were kept at room temperature for $5 \mathrm{~min}$. The absorbances were measured at $593 \mathrm{~nm}$ against a reagent blank using a Perkin-Elmer spectrophotometer. Calibration curve was calculated by using the ascorbic acid standard solutions $\left(y=0,717 x+0,008 ; R^{2}=0.999\right)$. The FRAP assay was done according to Benzie and Strain [34]. All experiments were carried out in triplicate.

\section{Statistical Analysis}

Glucosinolate and bioactivity values were evaluated from 10 plants per species and analyzed statistically, using ANOVA. Data obtained were evaluated with one way variance analysis and independent two-sample t-test. When appropriate, differences among mean of treatments were analyzed using Tukey.

\section{RESULTS}

\section{Protein, ash, fatty oil content and fatty acid composition of Isatis spp.}

I. aucherii (endemic), I. buschiana, I. candolleana (endemic), I. tinctoria subsp. corymbosa and a culture form of $I$. tinctoria were investigated in this study. The results of protein, ash and oil content and fatty acid composition in leaves of five Isatis species are given in Table 1 and 2. The average protein, ash and oil content of species ranged to 6.97 to $13.99 \%, 8.12$ to $17.99 \%$ and 4.03 to $9.8 \%$, respectively (Table 1 ). The highest protein contents were observed in I. tinctoria and $I$. buschiana with 13.99 and $13.32 \%$, respectively. The oil contents of $I$. tinctoria $(9.8 \%)$ and $I$. buschiana leaves $(8.02 \%)$ were higher than other species. The highest ash content was observed in I. tinctoria subsp. corymbosa and $I$. aucherii, which have hairy leaves. 
Table 1. Protein, ash and fatty oil content of the leaves of five Isatis species

\begin{tabular}{|l|c|c|c|}
\hline Species & Protein Content (\%) & Ash Content (\%) & Fatty Oil (\%) \\
\hline I. aucherii & $12.73 \pm 0.96$ & $15.34 \pm 1.03$ & $4.03 \pm 0.35$ \\
\hline I. buschiana & $13.32 \pm 0.82$ & $14.19 \pm 0.85$ & $8.02 \pm 0.83$ \\
\hline I. candolleana & $6.97 \pm 0.54$ & $11.99 \pm 0.68$ & $6.91 \pm 0.67$ \\
\hline I. tinctoria & $13.99 \pm 0.64$ & $8.12 \pm 0.75$ & $9.8 \pm 0.92$ \\
\hline I. tinctoria subsp. corymbosa & $8.54 \pm 0.25$ & $17.99 \pm 1.12$ & $4.91 \pm 0.44$ \\
\hline
\end{tabular}

Fatty acid analysis of plant extracts revealed 17-23 fatty acids in Isatis species. In $I$. buschiana, I. tinctoria subsp. corymbosa and I. tinctoria, the majority of fatty acids constitute the saturated fatty acids (SFA) (44.57, 50.23 and $44.51 \%$, respectively). SFA and polyunsaturated fatty acids (PUFA) in $I$. aucherii are approximately equal (36.07 and $36.73 \%$, respectively) and higher than monounsaturated fatty acid (27.2\%). In I. candolleana, PUFA was found to be higher than other fatty acids. Scientific reports showed that PUFA is beneficial in alleviating several diseases such as cardiovascular, inflammatory, heart diseases, atherosclerosis, autoimmune disorder and diabetes [35]. In endemic and native Isatis species, the ratio of PUFA fatty acids to total oil was found to be higher than I. tinctoria.

The major fatty acids of Isatis leaves were found to be palmitic, oleic, linoleic, arachidic and arachidonic acids. Arachidic acid was predominant in I. tinctoria subsp. corymbosa, I. buschiana and I. aucherii, while it was low in I. candolleana and I. tinctoria. The predominant fatty acids were palmitic, oleic and arachidonic acids in I. candolleana and I. tinctoria. In addition to similar staining properties of $I$. tinctoria and $I$. candolleana [21], fatty acid contents were found to be generally similar. Caprylic acid (8.57\%) and cis-10 Heptadecenoic acid $(7.12 \%)$ in I. tinctoria, cis-11- Eicosenoic acid in I. aucherii $(8.24 \%)$ and I. buschiana $(4.52 \%)$, elaidic acid $(6.99 \%)$ in $l$. tinctoria subsp. corymbosa and cis-4,7,10,13,16,19-Docosahexaenoic Acid (11.55\%) in I. buschiana were significantly different from the other Isatis species Fatty acid results were given in Table 2 and GC chromatogram of $I$. aucherii was shown in Figure 1.

Table 2. Fatty acid compositions (\%) of the leaves of five Isatis species

\begin{tabular}{|c|c|c|c|c|c|c|}
\hline & & I. aucherii & I. buschiana & $\begin{array}{c}\text { I. } \\
\text { candolleana }\end{array}$ & $\begin{array}{c}\text { I. tinctoria } \\
\text { subsp. } \\
\text { corymbosa }\end{array}$ & I. tinctoria \\
\hline $8: 0$ & Caprylic acid & - & - & $0.20 \pm 0.01$ & - & $8.57 \pm 0.06$ \\
\hline $12: 0$ & Lauric acid & $0.16 \pm 0.03$ & $0.08 \pm 0.03$ & $0.25 \pm 0.02$ & - & - \\
\hline $14: 0$ & Myristic acid & $0.30 \pm 0.08$ & $0.30 \pm 0.00$ & $0.75 \pm 0.01$ & $0.62 \pm 0.05$ & $0.34 \pm 0.01$ \\
\hline $15: 0$ & Pentadecanoic acid & $0.13 \pm 0.07$ & $0.09 \pm 0.01$ & - & - & - \\
\hline $16: 0$ & Palmitic acid & $7.11 \pm 0.06$ & $10.65 \pm 0.03$ & $17.77 \pm 0.03$ & $11.80 \pm 0.06$ & $19.95 \pm 0.02$ \\
\hline $17: 0$ & Heptadecanoic acid & - & $0.14 \pm 0.04$ & - & - & $0.16 \pm 0.03$ \\
\hline $18: 0$ & Stearic acid & $2.27 \pm 0.00$ & $2.47 \pm 0.03$ & $5.53 \pm 0.04$ & $3.69 \pm 0.01$ & $5.42 \pm 0.00$ \\
\hline
\end{tabular}




\begin{tabular}{|c|c|c|c|c|c|c|}
\hline & & I. aucherii & I. buschiana & $\begin{array}{c}l . \\
\text { candolleana }\end{array}$ & $\begin{array}{l}\text { I. tinctoria } \\
\text { subsp. } \\
\text { corymbosa }\end{array}$ & I. tinctoria \\
\hline $20: 0$ & Arachidic acid & $24.33 \pm 0.01$ & $30.49 \pm 0.01$ & $6.25 \pm 0.01$ & $33.68 \pm 0.06$ & $9.54 \pm 0.00$ \\
\hline $21: 0$ & Heneicosanoic acid & $0.14 \pm 0.03$ & - & - & - & - \\
\hline $22: 0$ & Behenic acid & $0.62 \pm 0.05$ & $0.35 \pm 0.03$ & $0.26 \pm 0.02$ & - & $0.24 \pm 0.05$ \\
\hline $24: 0$ & Lignoceric acid & $1.01 \pm 0.04$ & - & $0.37 \pm 0.00$ & $0.44 \pm 0.05$ & $0.29 \pm 0.04$ \\
\hline $16: 1$ & Palmitoleic acid & $0.28 \pm 0.03$ & $1.07 \pm 0.06$ & $1.07 \pm 0.03$ & $0.79 \pm 0.00$ & $0.96 \pm 0.02$ \\
\hline $17: 1$ & cis-10 Heptadecenoic acid & $0.12 \pm 0.02$ & $0.50 \pm 0.04$ & $0.62 \pm 0.04$ & $1.46 \pm 0.01$ & $7.12 \pm 0.03$ \\
\hline $18: 1$ & Oleic acid & $16.58 \pm 0.02$ & $13.01 \pm 0.03$ & $25.01 \pm 0.01$ & $13.39 \pm 0.02$ & $21.14 \pm 0.04$ \\
\hline $18: 1$ & Elaidic acid & - & $2.56 \pm 0.00$ & - & $6.99 \pm 0.01$ & $1.67 \pm 0.02$ \\
\hline $20: 1$ & cis-11- Eicosenoic acid & $8.24 \pm 0.02$ & $4.52 \pm 0.02$ & $1.26 \pm 0.01$ & $0.37 \pm 0.02$ & $0.35 \pm 0.01$ \\
\hline $22: 1$ & Erucic acid & - & - & - & - & $0.11 \pm 0.02$ \\
\hline $24: 1$ & Nervonic acid & $1.98 \pm 0.03$ & $1.32 \pm 0.01$ & $1.03 \pm 0.01$ & $1.93 \pm 0.00$ & $0.49 \pm 0.03$ \\
\hline $18: 2$ & Linoleic acid & $12.23 \pm 0.03$ & $7.97 \pm 0.01$ & $12.17 \pm 0.03$ & $10.60 \pm 0.03$ & $5.14 \pm 0.03$ \\
\hline $18: 3$ & Gama-Linolenic acid & $0.12 \pm 0.04$ & $0.34 \pm 0.02$ & $0.45 \pm 0.04$ & $1.11 \pm 0.03$ & $0.27 \pm 0.02$ \\
\hline $18: 3$ & Alfa-Linolenic acid & $0.92 \pm 0.00$ & $1.17 \pm 0.04$ & $0.59 \pm 0.01$ & $1.22 \pm 0.00$ & $0.22 \pm 0.01$ \\
\hline $20: 2$ & cis-11,14- Eicosadienoic acid & $0.63 \pm 0.01$ & $0.38 \pm 0.02$ & - & - & - \\
\hline $20: 3$ & cis-8,11,14- Eicosatrienoic acid & - & - & $0.19 \pm 0.02$ & - & $0.25 \pm 0.05$ \\
\hline $20: 3$ & cis-11,14,17- Eicosatrienoic acid & $0.61 \pm 0.04$ & $0.30 \pm 0.03$ & - & - & - \\
\hline $20: 4$ & Arachidonic acid & $19.25 \pm 0.03$ & $10.26 \pm 0.01$ & $25.56 \pm 0.03$ & $10.10 \pm 0.03$ & $17.07 \pm 0.01$ \\
\hline $22: 2$ & cis-13.16- Docosadienoic acid & $0.18 \pm 0.02$ & - & - & - & - \\
\hline $20: 5$ & $\begin{array}{l}\text { cis-5.8.11.14.17- } \\
\text { Eicosapentaenoic acid }\end{array}$ & $0.21 \pm 0.02$ & $0.48 \pm 0.04$ & - & $0.44 \pm 0.04$ & $0.10 \pm 0.05$ \\
\hline 22:6 & $\begin{array}{l}\text { cis-4,7,10,13,16,19- } \\
\text { Docosahexaenoic acid }\end{array}$ & $2.58 \pm 0.03$ & $11.55 \pm 0.01$ & $0.67 \pm 0.01$ & $1.37 \pm 0.01$ & $0.60 \pm 0.03$ \\
\hline & SFA & 36.07 & 44.57 & 31.38 & 50.23 & 44.51 \\
\hline & MUFA & 27.2 & 22.98 & 28.99 & 24.93 & 31.84 \\
\hline & PUFA & 36.73 & 32.45 & 39.63 & 24.84 & 23.65 \\
\hline
\end{tabular}


Intensity

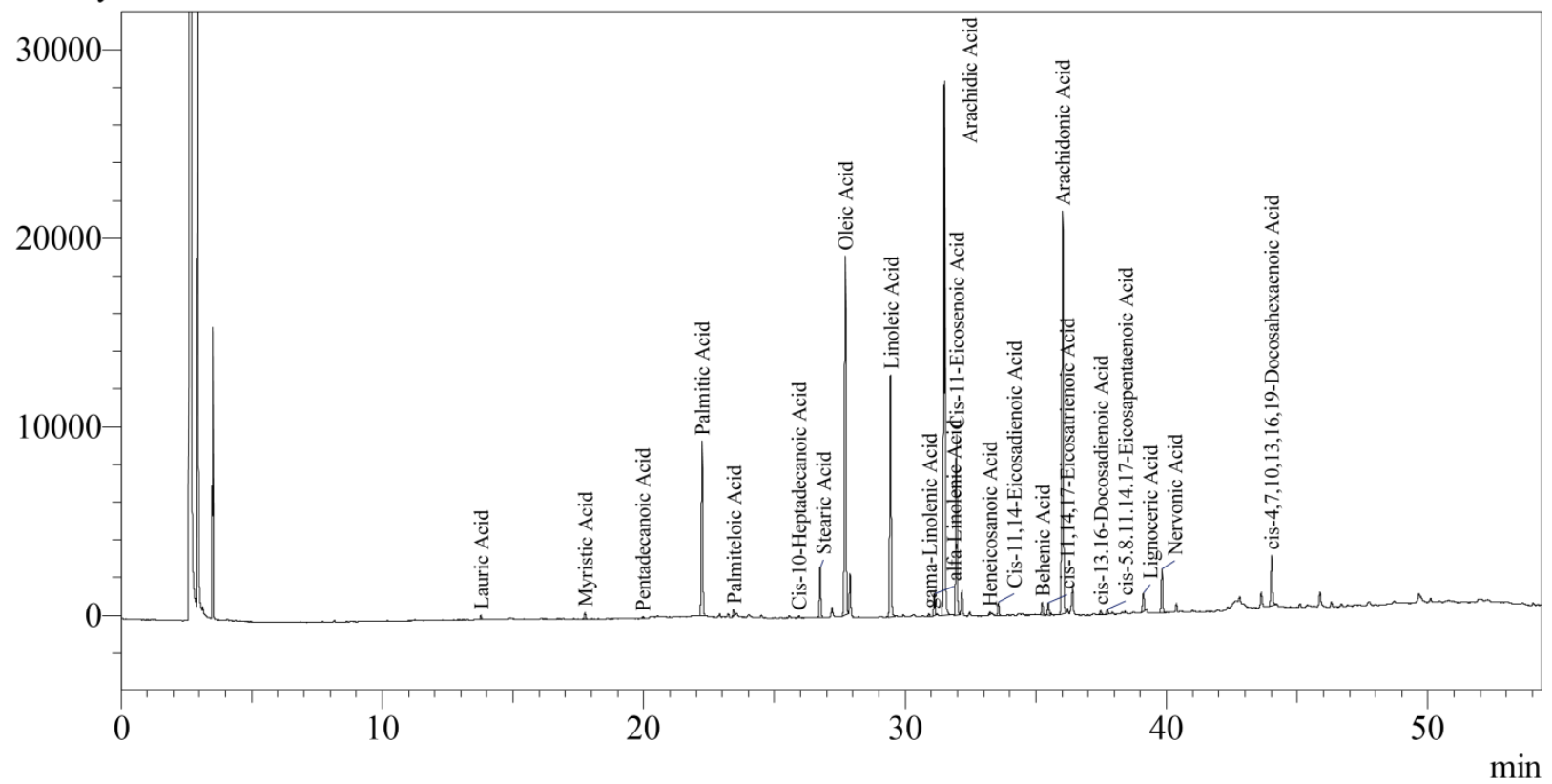

Figure 1. GC choramotogram of $I$. aucherii fatty acid analysis.

\section{Intact glucosinolate content of Isatis spp.}

The modified method for sample preparation and HPLC analysis was used to determine the content of five different glucosinolates in Isatis leaves. Extraction of intact glucosinolates was carried out with freeze-dried leaf samples using an ultrasonic bath and analyses were performed using HPLC. Table 3 shows the peak chromatograms of the extracts and glucosinolate contents in five different Isatis species, respectively. HPLC chromatogram of $I$. aucherii was shown in Figure 2. Different glucosinolate patterns were observed between the Isatis species. In comparison, the extract of $I$. aucherii and I. buschiana did not contain progoitrin, also epiprogoitrin was not be detected in I. tinctoria. Gluconapin and glucoerucin were the main glucosinolates in the I. aucherii, I. buschiana and I. tinctoria subsp. corymbosa extracts. Besides gluconapin, high amounts of epiprogoitrin and glucobrassicin were also detected in I. candolleana. On the other hand, glucobrassicin was the main glucosinolates in I. tinctoria.

Table 3. Glucosinolate content (in $\mu \mathrm{mol} / \mathrm{g}$ dry weight) in Isatis extracts

\begin{tabular}{|l|c|c|c|c|c|}
\hline \multirow{2}{*}{} & \multicolumn{3}{|c|}{ Aliphatic GLs $(\mu \mathrm{mol} / \mathrm{g})$} & $\begin{array}{c}\text { Indole GLs } \\
(\mu \mathrm{mol} / \mathrm{g})\end{array}$ \\
\cline { 2 - 6 } & Progoitrin & Epiprogoitrin & Gluconapin & Glucoerucin & Glucobrassicin \\
\hline I. aucherii & n.d. & $2.09 \pm 0.27^{\mathrm{b}}$ & $11.34 \pm 0.08^{\mathrm{b}}$ & $8.89 \pm 0.02^{\mathrm{a}}$ & $4.78 \pm 0.20^{\mathrm{b}}$ \\
\hline I. buschiana & n.d. & $2.19 \pm 0.16^{\mathrm{b}}$ & $14.78 \pm 0.22^{\mathrm{a}}$ & $4.79 \pm 0.25^{\mathrm{b}}$ & $1.85 \pm 0.28^{\mathrm{c}}$ \\
\hline I. candolleana & $0.72 \pm 0.05^{\mathrm{b}}$ & $5.27 \pm 0.12^{\mathrm{a}}$ & $8.79 \pm 0.03^{\mathrm{c}}$ & $2.17 \pm 0.46^{\mathrm{d}}$ & $4.56 \pm 0.27^{\mathrm{b}}$ \\
\hline I. tinctoria subsp. corymbosa & $0.51 \pm 0.06^{\mathrm{b}}$ & $2.62 \pm 0.42^{\mathrm{b}}$ & $6.98 \pm 0.52^{\mathrm{d}}$ & $2.93 \pm 0.27^{\mathrm{c}, \mathrm{d}}$ & $1.64 \pm 0.36^{\mathrm{c}}$ \\
\hline I. tinctoria & $1.42 \pm 0.19^{\mathrm{a}}$ & n.d. & $1.04 \pm 0.49^{\mathrm{y}}$ & $3.11 \pm 0.34^{\mathrm{c}}$ & $9.97 \pm 0.38^{\mathrm{a}}$ \\
\hline
\end{tabular}

$\mathrm{P}<0.05$ n.d.: not detected 


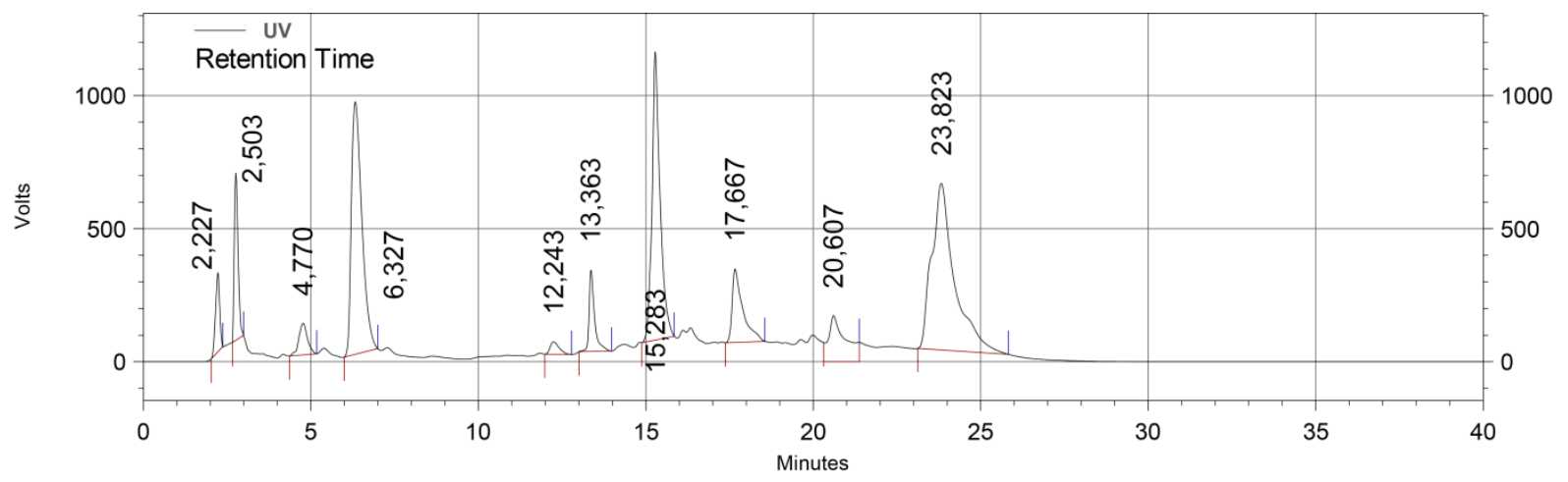

Figure 2. HPLC choramotogram of $I$. aucherii glucosinolate analysis.

\section{Total phenolic, flavonoid contents and antioxidant activity of Isatis spp.}

Total phenolic, flavonoid contents and antioxidant activity were measured and compared with that of the control which contained no antioxidant activity. The results of antioxidant activity determined by DPPH and FRAP methods; total phenolic and flavonoid contents in Isatis species are listed in Table 4. Total phenolic (8.90-19.16 $\left.\mathrm{mg} \mathrm{g}^{-1}\right)$ and flavonoid contents (115.6-430.6 $\left.\mathrm{g} \mathrm{g} \mathrm{g}^{-1}\right)$ were found to be rich in the studied Isatis species. I. buschiana contained the highest total phenolic and flavonoid amounts, in contrast to $I$. aucherii had the lowest values of total phenol and flavonoid content. Antioxidant activity was correlated with phenolic and flavonoid content, that high antioxidant activity was observed in I. buschiana whereas the least antioxidant activity was recorded in I. aucherii.

Table 4. Total phenolic and flavonoid contents with antioxidant activity in the extracts of Isatis species

\begin{tabular}{|c|c|c|c|c|}
\hline & $\begin{array}{l}\text { Total Phenolic Content } \\
\text { (mg GAE g-) }\end{array}$ & $\begin{array}{c}\text { Total Flavonoid } \\
\text { Content }(\mu \mathrm{g} \text { QE g-) }\end{array}$ & $\begin{array}{l}\mathrm{IC}_{50} \text { of } \mathrm{DPPH} \% \\
\left(\mathrm{mg} \mathrm{dw} \mathrm{mL}^{-}\right)\end{array}$ & $\begin{array}{c}\text { FRAP } \\
\left(\mu \mathrm{g} \text { AAE } g^{-}\right)\end{array}$ \\
\hline I. aucherii & $8.90 \pm 0.81^{c}$ & $120.6 \pm 2.58^{d}$ & $5.04 \pm 0.14^{d}$ & $4.17 \pm 0.37^{c}$ \\
\hline I. buschiana & $19.16 \pm 1.11^{\mathrm{a}}$ & $430.6 \pm 1.54^{\mathrm{a}}$ & $1.46 \pm 0.08^{a}$ & $20.17 \pm 0.79^{a}$ \\
\hline I. candolleana & $11.62 \pm 0.49^{b}$ & $121.4 \pm 1.9^{d}$ & $3.83 \pm 0.13^{c}$ & $12.15 \pm 0.30^{b}$ \\
\hline I. tinctoria subsp. corymbosa & $11.01 \pm 0.83^{b}$ & $237.2 \pm 2.4^{b}$ & $2.54 \pm 0.07^{b}$ & $11.15 \pm 0.30^{b}$ \\
\hline I. tinctoria & $12.44 \pm 0.66^{b}$ & $167.3 \pm 2.64^{c}$ & $3.8 \pm 0.12^{\mathrm{c}}$ & $12.64 \pm 0.88^{b}$ \\
\hline
\end{tabular}

$\mathrm{P}<0.05$

\section{DISCUSSION}

Lipids are responsible for the physical and chemical properties of food, and fatty acid esters of lipids are high in nutrients. Many lipid properties of food are explained regarding fatty acid composition [36]. cis-10-Heptadecenoic acid, which has some inhibitory activity against human cancer cells HL-60 [37], was found to be high in I. tinctoria (7.12\%). ALA, eicosapentaenoic acid and docosahexaenoic acid are omega 3; linoleic acid, gamma-linolenic acid and arachidonic acid are and omega 6; cis-11-eicosanoic acid, oleic 
acid and nervonic acid are omega 9 fatty acids. These fatty acids usually provide good cholesterol levels. In addition, they are beneficial to skin problems (e.g. psoriasis, eczema, dryness and pruritus), cardiovascular health, brain development, strengthening of the body's resistance, antimicrobial and anticancer [38-40]. Therefore, a diet rich in omega 3-6-9 foods is essential regarding our health. Caprylic acid was found in coconut fat $(7 \%)$ and also present in breast milk fat $[41,42]$. Erucic, oleic, linolenic, and linoleic acids were found to be the abundant fatty acids in seeds of several Isatis species [19,20,43]. It should be noted that erucic acid was one of the major fatty acids in the seeds of Isatis species [20], in contrast to the leaves of tested Isatis species, which have no or very low $(0.11 \%$ in I. tinctoria) erucic acid, in this study. Emam et al. [44] reported that the major fatty acids of $I$. microcarpa were arachidic (34.6\%), palmitic (27.2\%), linolenic (19.4\%), linoleic $(8.4 \%)$ and stearic $(5.3 \%)$ acids. High ratio of oleic acid and less than $3 \%$ and $2 \%$ ratios of linoleic acid and erucic acid, respectively, is desired for oils. Besides, high concentration of essential fatty acids in oils is essential for nutritional purposes [45]. According to fatty acid results, Isatis oils meet these criteria.

High glucobrassicin content in I. tinctoria was also reported by Elliott and Stove [14], Galetti et al. [46] and Mohn et al. [1]. The flower buds of $I$. canescens contained high gluconapin and glucobrassicin [18]. Epiprogoitrin was the main glucosinolate in I. indigotica seeds [47]. To the best of our knowledge, there is no available data on the glucosinolate contents of I. buschiana, I. aucherii, I. tinctoria subsp. corymbosa and I. candolleana, and glucosinolates of these plants were reported firstly in this study. The absence of some glucosinolates or the differences of quantities is related to the difference in species, localities, individuals, soil, and climate [48].

Several studies reported a correlation between phenolic content and antioxidant activity in some plant extracts $[49,50]$. The total phenolic content of $I$. tinctoria ranged from 4.18 to $90.44 \mathrm{mg}$ GAE g $[24,51,52]$. Li et al. [24] measured the antioxidant activity of $I$. tinctoria using FRAP and TEAC methods, and the results were $12.21 \mu \mathrm{mol} F e(\mathrm{III}) \mathrm{g}^{-}$and $5.81 \mu \mathrm{mol}$ Trolox g-, respectively. Results of total phenolic content and antioxidant activity $\left(\mathrm{IC}_{50}\right.$ of $\mathrm{DPPH} \%$ ) from the various extracts of $I$. indigotica herb varied between $1.82-5.94 \mathrm{mg} \mathrm{GAE} \mathrm{g}$ and $0.38-3.5 \mathrm{mg} \mathrm{dw} \mathrm{mL'}$, respectively [25]. Total phenolic content and antioxidant capacity of $I$. indigotica root were reported as $4.5 \mathrm{mg} \mathrm{GAE} \mathrm{g}^{-}$and $0.6 \mu \mathrm{mol}$ Trolox $\mathrm{g}^{-}$, respectively [23]. Flowers of $I$. floribunda and $I$. canescens were also studied and total phenolic and flavonoid content were found in the range of $22.3-37.09 \mathrm{mg} \mathrm{GAE} \mathrm{g}$ and $5.3-12.65 \mathrm{mg} \mathrm{g}^{-}$, respectively $[18,26]$. Genetics, agronomic, geographical region, environmental factors, extraction procedures influence the levels of bioactive components of plants $[53,54]$.

\section{CONCLUSION}

Endemic $I$. aucheri and $I$. candolleana, native $I$. buschiana and $I$. tinctoria subsp. corymbosa and well studied $I$. tinctoria were evaluated for their bioactive compounds in this study. Variations were found in fatty acid, glucosinolate, total phenolic and flavonoid content and antioxidant capacity among the tested plants. It was observed that there is a relationship between total phenolic content, and antioxidant activity in selected Isatis species, revealing that phenolic compounds are the dominant contributor of antioxidant capacities of these plants. The results are highlighted that $I$. buschiana is a rich source of protein, arachidic acid, gluconapin, total phenol and flavonoid content, and antioxidant activity. Therefore, $I$. buschiana could be a promising plant for the application of antioxidants in drug development. These findings highlight that Isatis species represent a good source of bioactive compounds. Because of the rich source of dietary antioxidants, glucosinolates, and fatty acids, possible health-promoting effects of studied Isatis spp. should be investigated using mild cooking methods, like steaming, in future studies. After the positive role of these species for human health had been established, dried standardized extracts could be produced. Cultivation and agronomic studies would be required to investigate the variability among Isatis populations, 
to reproduce genotypes with consistent characters and to set up suitable breeding procedures.

Acknowledgments: This research was funded by Kahramanmaras Sutcu Imam University, grant number 2012/3-23M.

Conflicts of Interest: The funders had no role in the design of the study; in the collection, analyses, or interpretation of data; in the writing of the manuscript, or in the decision to publish the results.

\section{REFERENCES}

1. Mohn, T.; Cutting, B.; Ernst, B.; Hamburger, M. Extraction and analysis of intact glucosinolates-A validated pressurized liquid extraction/liquid chromatography-mass spectrometry protocol for Isatis tinctoria and qualitative analysis of other cruciferous plants. $J$ Chromatogr A. 2007; 1166(1), 142-151.

2. Troyer, J.K.; Stephenson, K.K.; Fahey, J.W. Analysis of glucosinolates from broccoli and other cruciferous vegetables by hydrophilic interaction liquid chromatography. J Chromatogr A. 2001, 919(2), 299-304.

3. Rask, L.; Andréasson, E.; Ekbom, B.; Eriksson, S.; Pontoppidan, B.; Meijer, J. Myrosinase: gene family evolution and herbivore defense in Brassicaceae. In: Plant Molecular Evolution. Netherlands: Springer; 2000. p. 93-113.

4. Shapiro, T.A.; Fahey, J.W.; Wade, K.L.; Stephenson, K.K.; Talalay, P. Human metabolism and excretion of cancer chemoprotective glucosinolates and isothiocyanates of cruciferous vegetables. Cancer Epidem Biomar. 1998, 7(12), 1091-1100.

5. Song, L.; lori, R.; Thornalley, P.J. Purification of major glucosinolates from Brassicaceae seeds and preparation of isothiocyanate and amine metabolites. J Sci Food Agr. 2006, 86(8), 1271-1280.

6. Brock, A.; Herzfeld, T.; Paschke, R.; Koch, M.; Dräger, B. Brassicaceae contain nortropane alkaloids. Phytochemistry. 2006, 67(18), 2050-2057.

7. Al-Shehbaz, I.A.; Mutlu, B.; Dönmez, A.A. The Brassicaceae (Cruciferae) of Turkey, updated. Turk J Bot. 2007, 31, 327-336.

8. Moreno, D.A.; Carvajal, M.; López-Berenguer, C.; García-Viguera, C. Chemical and biological characterisation of nutraceutical compounds of broccoli. $J$ Pharmaceut Biomed. 2006, 41(5), 1508-1522.

9. Tripathi, M.K.; Mishra, A.S. Glucosinolates in animal nutrition: A review. Anim Feed Sci Tech. 2007, 132(1), 1-27.

10. Comlekcioglu, N.; Efe, L.; Karaman, S. Effects of different sowing times on the yield and agronomic characters of Isatis tinctoria and Isatis buschiana in Kahramanmaras conditions. JOTAF. 2014, 11(1), 67-78.

11. Davis, P.H. Flora of Turkey and the East Aegean Islands (Vol. 10). Edinburgh University Press; 1965.

12. Maugard, T.; Enaud, E.; Choisy, P.; Legoy, M.D. Identification of an indigo precursor from leaves of Isatis tinctoria (Woad). Phytochemistry. 2001, 58(6), 897-904.

13. Hamburger, M. Isatis tinctoria-From the rediscovery of an ancient medicinal plant towards a novel anti-inflammatory phytopharmaceutical. Phytochem Rev. 2002, 1(3), 333-344.

14. Elliott, M.C.; Stowe, B.B. Distribution and variation of indole glucosinolates in woad (Isatis tinctoria L.). Plant Physiol. 1971, 48(4), 498-503.

15. Mohn, T.; Plitzko, I.; Hamburger, M. A comprehensive metabolite profiling of Isatis tinctoria leaf extracts. Phytochemistry. 2009, 70(7), 924-934.

16. Mohn, T.; Hamburger, M. Glucosinolate pattern in Isatis tinctoria and I. indigotica seeds. Planta Med. 2008, 74(8), 885-888.

17. Emam, S.S.; El-Moaty, H.A. Glucosinolates, phenolic acids and anthraquinones of Isatis microcarpa (Boiss) and Pseuderucaria clavate (Boiss \& Reut.) family: Cruciferae. J Appl Sci Res. 2009, 5(12), 2315-2322.

18. Galletti, S.; Bagatta, M.; Branca, F.; Argento, S.; De Nicola, G.R.; Cianchetta, S.; ... Ninfali, P. Isatis canescens is a rich source of glucobrassicin and other health-promoting compounds. $J$ Sci Food Agr. 2015, 95(1), 158-164. 
19. Bagci, E.; Özçelik, H. Fatty acid and tocochromanol patterns of some Isatis L. (Brassicaceae) species from Turkey. Pakistan J Bot. 2009, 41(2), 639-646.

20. Kizil, S.; Turk, M.; Cakmak, O.; Ozguven, M.; Khawar, K.M. Microelement Contents and Fatty Acid Compositions of some Isatis Species Seeds. Not Bot Horti Agrobo. 2009, 37(1), 175.

21. Comlekcioglu, N.; Efe, L.; Karaman, S. Extraction of Indigo from Some Isatis species and Dyeing Standardization Using Low-technology Methods. Braz Arch Biol Techn. 2015, 58(1), 96-102.

22. Jamali, A.; Grand, E.; Morreel, K.; Marcelo, P.; Gontier, E.; Dauwe, R. Phenylpropanoid profiling reveals a class of hydroxycinnamoyl glucaric acid conjugates in Isatis tinctoria leaves. Phytochemistry. 2017, 144, 127-140.

23. Cai, Y.; Luo, Q.; Sun, M.; Corke, H. Antioxidant activity and phenolic compounds of 112 traditional Chinese medicinal plants associated with anticancer. Life Sci. 2004, 74(17), 2157-2184.

24. Li, H.B.; Wong, C.C.; Cheng, K.W.; Chen, F. Antioxidant properties in vitro and total phenolic contents in methanol extracts from medicinal plants. LWT-Food Sci Technol. 2008, 41(3), 385-390.

25. Wang, X.H. Ultrasound assisted extraction for analysis of total phenolic content and antioxidant activity of medicinal plants. Afr J Microbiol Res. 2013, 6(40), 6847-6852.

26. Karakoca, K.; Ozusaglam, M.A.; Cakmak, Y.S.; Erkul, S.K. Antioxidative, antimicrobial and cytotoxic properties of Isatis floribunda Boiss. ex Bornm. extracts. EXCLI Journal. 2013, 12, $150-167$.

27. UNIEN 14775. Solid biofuels, determining the ash content, 2010.

28. AOAC. Official method of analysis. Association of official analytical chemists 15th.edition; 1990. p. 66-88.

29. Siciliano, C.; Belsito, E.; De Marco, R.; Di Gioia, M.L.; Leggio, A.; Liguori, A. Quantitative determination of fatty acid chain composition in pork meat products by high resolution $1 \mathrm{H}$ NMR spectroscopy. Food Chem. 2013, 136(2), 546-554.

30. Blainski, A.; Lopes, G.C.; De Mello, J.C.P. Application and analysis of the Folin Ciocalteu method for the determination of the total phenolic content from Limonium brasiliense L. Molecules. 2013, 18(6), 6852-6865.

31. Chang, C.C.; Yang, M.H.; Wen, H.M.; Chern, J.C. Estimation of total flavonoid content in propolis by two complementary colorimetric methods. J Food Drug Anal. 2002, 10(3), 178-182.

32. Al-Reza, S.M.; Rokonuzzaman, M.; Afroz, M.; Hussain, M.; Rashid, M.A.; Rahman, A. Chemical Composition and Antioxidant Activity of Essential Oil and Organic Extracts of Premna integrifolia Linn. Braz Arch Biol Techn. 2016, 59, 1-8.

33. Brand-Williams, W.; Cuvelier, M.E.; Berset, C.L.W.T. Use of a free radical method to evaluate antioxidant activity. LWT-Food Sci Technol. 1995, 28(1), 25-30.

34. Benzie, I.F.; Strain, J.J. The ferric reducing ability of plasma (FRAP) as a measure of "antioxidant power": the FRAP assay. Anal Biochem. 1996, 239(1), 70-76.

35. Finley, J.W., Shahidi, F. The chemistry, processing, and health benefits of highly unsaturated fatty acids: An overview. In (Eds. Shahidi F, Finley JW) Omega-3 fatty acids: Chemistry, nutrition, and health effects. 2001; Vol.788, pp. 2-11, ACS Symposium Series.

36. Ayaz, F.A.; Glew, R.H.; Millson, M.; Huang, H.S.; Chuang, L.T.; Sanz, C.; Hayırlıoglu-Ayaz, S. Nutrient contents of kale (Brassica oleraceae L. var. acephala DC.). Food Chem. 2006, 96(4), 572-579.

37. Fukuzawa, M.; Yamaguchi, R.; Hide, I.; Chen, Z.; Hirai, Y., Sugimoto, A.; ... Nakata, Y. Possible involvement of long chain fatty acids in the spores of Ganoderma lucidum (Reishi Houshi) to its anti-tumor activity. Biol Pharm Bull. 2008, 31(10), 1933-1937.

38. Asif, M. Health effects of omega-3, 6, 9 fatty acids: Perilla frutescens is a good example of plant oils. Orient Pharm Exp Med. 2011, 11(1), 51-59.

39. De Caterina, R. n-3 fatty acids in cardiovascular disease. $N$ Engl J Med. 2011, 364(25), 2439-2450.

40. Çakmakçi, S.; Kahyaoğlu, D.T. Yağ Asitlerinin Sağlık ve Beslenme Üzerine Etkileri. Türk Bilimsel Derlemeler Dergisi. 2012, 5(2): 133-137.

41. Beare-Rogers, J.L.; Dieffenbacher, A.; Holm, J.V. Lexicon of lipid nutrition (IUPAC Technical Report). Pure Appl Chem. 2001, 73(4), 685-744.

42. Takeuchi, H.; Sekine, S.; Kojima, K.; Aoyama, T. The application of medium-chain fatty acids: edible oil with a suppressing effect on body fat accumulation. Asia Pac J Clin Nutr. 2008, 17(1), 320-323. 
43. Li, T.; Qu, X.Y.; Zhang, Q.A.; Wang, Z.Z. Ultrasound-assisted extraction and profile characteristics of seed oil from Isatis indigotica Fort. Ind Crop Prod. 2012, 35(1), 98-104.

44. Emam, S.S.; El-Moaty, H.I.A.; El-Mohamed, S.A. Primary metabolites and flavonoid constituents of Isatis microcarpa J. Gay ex Boiss. J Nat Prod (India). 2010, 3, $12-26$.

45. Kırıcı, S.; İbrikçi, H.; Gür, M.A.; Özel, A.; Karaaslan, D.; Kırpık, M.; Akıncı, C.; Gül, I.; Inan, M. Güneydoğu Anadolu Bölgesi' nde kolza (Brassica napus L.) çeşitlerinde azot miktarı ve bitki yoğunluğunun tohum verimi ve yağ oranına etkisi. TÜBITAK TOGTAG TARP Proje No. 1778, 2001: 1-54. Proje sonuç Raporu. 2004.

46. Galletti, S.; Barillari, J.; lori, R.; Venturi, G. Glucobrassicin enhancement in woad (Isatis tinctoria) leaves by chemical and physical treatments. J Sci Food Agr. 2006, 86(12), 1833-1838.

47. Angelini, L.G.; Tavarini, S.; Antichi, D.; Bagatta, M.; Matteo, R.; Lazzeri, L. Fatty acid and glucosinolate patterns of seed from Isatis indigotica Fortune as bioproducts for green chemistry. Ind Crop Prod. 2015, 75, 51-58.

48. Ferioli, F.; Giambanelli, E.; D'Antuono, L.F.; Costa, H.S.; Albuquerque, T.G.; Silva, A.S.; ... Koçaoglu, B. Comparison of leafy kale populations from Italy, Portugal, and Turkey for their bioactive compound content: phenolics, glucosinolates, carotenoids, and chlorophylls. J Sci Food Agric. 2013, 93(14), 3478-3489.

49. Velioglu, Y.S.; Mazza, G.; Gao, L.; Oomah, B.D. Antioxidant activity and total phenolics in selected fruits, vegetables, and grain products. J Agr Food Chem. 1998, 46(10), 4113-4117.

50. Thaipong, K.; Boonprakob, U.; Crosby, K.; Cisneros-Zevallos, L.; Byrne, D.H. Comparison of ABTS, DPPH, FRAP, and ORAC assays for estimating antioxidant activity from guava fruit extracts. J Food Compos Anal. 2006, 19(6), 669-675.

51. Peschel, W.; Sánchez-Rabaneda, F.; Diekmann, W.; Plescher, A.; Gartzía, I.; Jiménez, D.; ... Codina, C. An industrial approach in the search of natural antioxidants from vegetable and fruit wastes. Food Chem. 2006, 97(1), 137-150.

52. Li, S.; Li, S.K.; Gan, R.Y.; Song, F.L.; Kuang, L.; Li, H.B. Antioxidant capacities and total phenolic contents of infusions from 223 medicinal plants. Ind Crop Prod. 2013, 51, 289-298.

53. Yang, M.; Zheng, C.; Zhou, Q.; Huang, F.; Liu, C.; Wang, H. Minor components and oxidative stability of cold-pressed oil from rapeseed cultivars in China. J Food Comp Anal. 2013, 29(1), 1-9.

54. Filipiak-Szok, A.; Kurzawa, M.; Szłyk, E. Evaluation of antioxidants in Dong quai (Angelica sinensis) and its dietary supplements. Chem Pap. 2014, 68(4), 493-503. 